\title{
Ruthless Picking Destroys Our Wild Flowers
}

\section{Winnipeg Free Press}

The coming of spring prompted Dr. W. R. Leslie, superintendent of the experimental station, Morden, Man., to make the following comment on western Canadian wild flowers:

"Wild flowers are among the wonderful gifts of nature. They deck the landscape in woodland, hillside, meadow and swamp. Most unfortunately some of these beauties of the outdoors are becoming only memories due to ruthless picking and careless pulling of plants.

"Among the wild flowers which should not be picked are: all orchids including lady's slipper, lilies, pitcher plants, shooting stars, trilliums, columbine, prairie mallow, scarlet gaura, bunchberry, dogwood, bluebells, water lilies, Indian pipe, spotted wintergreen, anemone, fringed gentian, and walking ferns.

"The following group of wild flowers may be picked in small measure providing the roots are not disturbed: Hepatica, dogtooth violet, bloodroot, ferns, iris, meadow rue, clematis, wild geranium, marsh marigold, gaillardia, marsh pink, beardtongue, common violets, closed gentian, yellow wood sorrel, Solomon's seal, lupine, meadowsweet, and wild roses."

\section{Small Wood Anemone}

Ronald Hooper, Somme, Sask.

Last spring I found a patch of Small Wood Anemone (A. quinquefolia), covering an area of about 100 square feet. They were growing on unbroken high ground among short aspen saplings. They were beautiful - even more beautiful than our other anemonies because of the pinkish tinge of the sepals, and the dense mat they formed.

A specimen of this plant was identified for me by A. C. Budd. This may be the first record for Saskatchewan. It has been found at Dauphin, Manitoba.

Other anemonies I have in my collection of plants of the Somme area are:

Canada Anemone (A. canadensis) - very common in deciduous woods.

Long-fruited Anemone (A. cylindrica) - fairly common in deciduous woods.

Cut-leaved Anemone (A. multifida) - one plant found on a rocky open hilltop.

\section{The Brown Thrasher}

John E. Nixon

Wauchope, Sask.

Not yours the haunts of robin, dove or wren

Who ever seek our dwellings; your demesne

Is set in lonely thickets lush and green,

Far off from gardens and the homes of men.

Ónly on sunny mornings now and then,

Before the leaves have lost their dewy sheen,

And choosing rather to be heard than seen,

You wake us with your ecstasies again.

Shy Chorister, whose depth and power of song

Ranges all octaves with a master's ease;

The sweetest singer of all prairie birds,

Whether you pipe your music full and strong

Or lull yourself with low soliloquies

And tell your love in almost human words. 